DOI https://doi.org/10.30525/978-9934-26-000-1-31

\title{
ОСОБЛИВОСТІ КОМУНІКАЦІЇ ЗІ СТУДЕНТСЬКОЮ МОЛОДДЮ В УМОВАХ ІНФОРМАЦІЙНИХ ПОТОКІВ
}

\section{Павлишин Н. I.}

асистент кафедри журналістики та засобів масової комунікаџії

Інститут права, психології та інноваційної освіти Національного університету «Львівська політехніка»

м. Львів, Україна

Актуальність дослідження. Надмір інформації, можливість кількома кліками отримувати доступ фактично до будь-яких даних, призводить до того, що споживачі, а зокрема молодь, не готові триваліше зупиняти свою увагу на повідомленнях. Тож часто важлива інформація проходить потоком поза їхньою увагою і це нівелює звиклі форми комунікації.

Мета роботи. Вивчення методів ефективної комунікації зі студентами Національного університету «Львівська політехніка», використовуючи інструментарій різноманітних соціальних мереж.

Об'єкт дослідження. Формати комунікації соціальних мереж Facebook, Instagram, Yelegrsm, YouTube, TikTok.

Предмет дослідження. Форми донесення інформації до аналізованої групи (студентської молоді).

Наукова новизна результатів роботи. Здійснено опитування студентів Львівської політехніки щодо їхнього цільового пошуку інформації, що стосується діяльності університету. А також проаналізовано підходи та інструменти застосування можливостей соціальних мереж у комунікаційній діяльності університету.

Про те, що сучасна молодь найчастіше використовує інформацію 3 інтернету, говорять вже щонайменше десятиліття. $€$ низка досліджень, які підтверджують, що це явище масштабується з кожним роком.

Ще в 2013 році, провівши соціологічне дослідження «Сучасна молодь України», Інститут Горшеніна підсумував, що 71,9\% респондентів (опитували молодь у 24 областях і в, тоді ще не окупованій, Автономній Республіці Крим) щодня користується інтернетом. Більшість опитаних $-65,8 \%$ - інтернет використовують для пошуку інформації. Цікаво також, що вже сім років тому молодь $-58,7 \%$ - інформацію для роботи та навчання шукала здебільшого в інтернеті. [3]

Ще більше зросла значимість інтернет-ресурсів у час карантинних обмежень. Сьогодні в онлайні відбувається не лише спілкування, а й навчання, робота, напрацювання нових партнерств та проєктів. 
У значній мірі соціальні мережі є основним джерелом, звідки молодь отримує інформацію.

Соціальні мережі уможливлюють охоплення більшого сегменту цільової аудиторії, миттєве донесення необхідної інформації, поширення їі одним кліком, отримання швидкої реакції через коментарі та змогу оперативно відповісти на них.

Ще однією перевагою комунікації через різні інтернет-мережі $є$ мультимедійна подача інформації, адже окрім тексту можна доєднувати відео- чи аудіоматеріали, а також досить багато візуального контенту, або ж поєднувати візуальний та текстовий зміст у постерах, гіфках, які швидше привертають увагу і ними молодь частіше ділиться з іншими.

Для університетів інтернет є дієвим альтернативним шляхом донесення інформації до працівників і студентів. Провівши опитування серед молоді Національного університету «Львівська політехніка», отримали результати, які підтвердили, що найчастіше про події у своєму закладі вищої освіти молодь дізнається саме 3 інтернету. Так, із 1741 опитаних - 1041, тобто 59\%, відповіли, що новини про університет дізнається 3 різних ресурсів в інтернеті. 29\% опитаних цікавить інформація про можливості для них. 40\% респондентів найбільше цікавляться інформацією про навчальний процес. А майже 19\% шукають інформацію про досвід навчання інших студентів.

Та поміж тим, комунікація через сайт і соціальні мережі потребує чіткого розмежування форматів подачі інформації. Розширюючи комунікаційні канали, ми повинні подбати, щоб подана інформація позитивно впливала на імідж університету, використовуючи різноманітні формати донесення повідомлень, маємо враховувати специфіку тієї чи іншої соціальної мережі.

Як зазначає у своєму дослідженні наукова співробітниця Центру цифрової журналістики при Колумбійському університеті Клер Вардль, сьогодні «замість того, аби щось фільмувати, і за умови запиту надсилати зйомку в новинарне агентство, люди миттєво фіксують побачене і завантажують картинку на Facebook, YouTube або Twitter» [2].

Така ж тенденція поширена і в студентському середовищі - молодь прагне миттєво поділитися побаченим чи почутим. I це варто враховувати, коли хочемо донести певну важливу інформацію - формат подачі має привертати увагу і викликати бажання поділитися тим, що дізналися.

Серед важливих підходів у комунікації є створення відчуття залученості до процесів, які відбуваються в університеті. Тобто подання інформації має показувати прозорість і відкритість роботи.

Варто враховувати також і те, що постійне налагодження прямої та оперативної комунікації зі студентами дає можливість якісніше співдіяти з ними. Це особливо відчутно, коли виникає необхідність швидко доносити певні інформаційні повідомлення для широко кола споживачів. 
Молода науковиця Катерина Долженко у своїй роботі «Особливості ефективної взаємодії соціальних мереж та українських інтернет-3МІ» $[1$, c. 6] наголошує, що «функціонування віртуальних спільнот у режимі онлайн відбувається незалежно від географічних і соціальних меж, державних кордонів. Користувачі стають залученими до інформаційного простору та отримують більше можливостей для спілкування». Це ж ми спостерігаємо нині, в умовах нових карантинних викликів, коли студенти, навчаючись дистанційно, не залежно від фізичного місця перебування, можуть легко комунікувати між собою, а також дізнаватися найважливішу інформацію про діяльності університету i, ділячись власним баченням розв'язання тих чи інших питань, до певної міри впливати на прийняття важливих рішень керівництвом університету.

Отже, зважаючи на сучасні тенденції інформаційного простору, задля ефективної комунікації зі студентами, найважливіше подавати інформацію зокрема й у звичних для молоді форматах, надаючи перевагу лаконічним текстовим формам та відповідним візуальним доповненням.

\section{Література:}

1. Долженкова К. Особливості ефективної взаємодії соціальних мереж та українських інтернет-3МІ [Електронний ресурс] / Катерина Долженкова // Полтава : ПНПУ імені В. Г. Короленка, - 2017. URL: $\quad$ https://kubg.edu.ua/images/stories/Departaments/nmc.nd/student_ nauka/2017-2018/roboty_peremozhciv/suchasn-zhurn.pdf.

2. Посібник з верифікації. Розділ 3: Перевірка створеного користувачами контенту (СКК) [Електронний ресурс] / Texty.org.ua, - 2014. URL: https://texty.org.ua/archive-books/55735/posibnyk-z-veryfikatsiyi-557 35/\#56020.

3. Більше половини української молоді щодня користуються соцмережами - дослідження [Електронний ресурс] / Українська правда, 2013. - URL: https://life.pravda.com.ua/society/2013/04/2/125563/. 